\title{
Tax Evasion - Generating and Complementary Effect of the Shadow Economy
}

\author{
Ioana Lazarescu ${ }^{\star}$, Viorica Ioan ${ }^{\star \star}$, Costinela Fortea ${ }^{\star \star \star}$
}

\begin{tabular}{l}
\hline \multicolumn{1}{c}{ A R T I C L E I N F O } \\
\hline Article history: \\
Accepted November 2020 \\
Available online December 2020 \\
\hline JEL Classification \\
E60, H26 \\
Keywords: \\
Shadow economy, Tax evasion, \\
GDP, VAT
\end{tabular}

1. Introduction

The shadow economy and tax evasion can cause serious damage to a country's economy. Tax evasion is one of the most important complex economic and social phenomena that states face, and whose undesirable consequences seek to be limited, eradication being impossible. The effects of tax evasion have a direct impact on tax revenue levels.

One of the main causes is the corruption manifested in the fiscal financial field, but also as a background of the entire activity of the enterprise, which diminishes the exigency and quality of the supervision and control act, and of preventing such illegal activities and at the same time increases tolerance and the firmness of the application of the act of justice by unjustifiably light sanctions, especially of an administrative nature, which do not have the necessary effect, but on the contrary, encourages the repetition of such illegal acts.

Tax evasion is determined by the action of several factors, the most important being: the excessive size of tax burdens, insufficient education of taxpayers, lack of effective control by well-trained staff, the existence of defective legislation that allows evasion of taxes.

\section{Literature review}

In the specialty literature we find different definitions of tax evasion. Tax evasion can be defined as the totality of licit or illicit procedures by means of which natural or legal persons, evade in whole or in part the taxable matter and consists in the willful non-fulfillment of the fiscal obligations by the taxpayer. (Voicu C., 1997).

Tax evasion is a negative economic phenomenon, present in all economies of the world, in varying proportions, determined by many factors. (Alm, Martinez-Vazquez, 2007).

According to Văcărel I. (2008) the definition of tax evasion is "the totality of licit or illicit procedures by means of which the interested parties evade, in whole or in part, their taxable matter to the obligations established by the fiscal laws". Regarding the classification of this phenomenon, the author shows that "evasion can be committed by a person under the protection of the law (legal evasion) or in violation of legal provisions (fraudulent evasion)."

The shadow economy appears in the literature under different names: hidden, gray, parallel, unobserved, unofficial, annexed, dangerous, ghostly, invisible, occult, dual, informal, illegal, underground economy (Brasoveanu I.V., 2010, Schneider F., 2007, 2015).

This shadow economy exists in all countries of the world, but in different proportions of gross domestic product (GDP). The definition given by Pierre Pestieau, (Pestieau, 1989, quoted by Radulescu S., 2007), according to which the shadow economy represents "the set of economic activities carried out outside 
criminal, social or fiscal laws or which escape the inventory of national accounts", is considered by specialists as the broadest definition of the shadow economy (Rădulescu S., 2007). There is a rich literature on the possible causes of the shadow economy, the main factors being (Caballé, Panadés, 2007, Levaggi, 2007, McGee, 2005, Torgler, Valev, 2007 quoted by Brasoveanu I. V., 2010):

* fiscal pressure exerted by taxation (Caballé, Panadés, 2007);

$\$$ the pressure exerted by the regulations imposed by the state (Levaggi, 2007);

* citizens' attitude towards the state (McGee, 2005, Torgler, Valev, 2007).

According to the definition (Choi and Thum, 2005), the shadow economy is made up of activities that are not recorded in government statistics.

According to the OECD (2002) on measuring the shadow economy, it contains:

* shadow production: productive and legal activities but which are deliberately hidden from the authorities to avoid paying taxes;

\# illegal production;

* the production of the informal sector, activities within the household sector or in other units that are unregistered;

* production of households for own final consumption.

The non-declaration of the full VAT together with the evasion of the income tax constitutes the most important part of the informal economy, according to the estimates of the National Institute of Statistics (NIS).

The shadow economy is at the point where it has a rather strong negative impact on tax revenues, but especially on gross domestic product and economic growth. The impact on a country's economy becomes stronger as the size of the shadow economy becomes larger, becoming a real problem for many countries.

\section{The dimensions of Romania's shadow economy}

The shadow economy, also known as the hidden economy, gray, black, refers to illegal economic activities, either with illegal products and services, or with legal products or services, in which case the persons involved carry out economic operations with such products or services. without paying taxes. Another economic activity in the shadow economy is tax evasion.

Changes in certain tax rates are a cause. Changes in people's opportunities to evade taxes is another cause. Such changes may be reflected in changes in the sectors in which people are employed, the type of employment, or the structures of the market.

Table 1. Size of the Shadow Economy of European Countries over 2009-2019 (in \% of off. GDP)

\begin{tabular}{cccccccccccc}
\hline Country & $\mathbf{2 0 0 9}$ & $\mathbf{2 0 1 0}$ & $\mathbf{2 0 1 1}$ & $\mathbf{2 0 1 2}$ & $\mathbf{2 0 1 3}$ & $\mathbf{2 0 1 4}$ & $\mathbf{2 0 1 5}$ & $\mathbf{2 0 1 6}$ & $\mathbf{2 0 1 7}$ & $\mathbf{2 0 1 8}$ & $\mathbf{2 0 1 9}$ \\
\hline Bulgaria & 32,5 & 32,6 & 32,3 & 31,9 & 31,2 & 31 & 30,6 & 30,2 & 29,6 & 30,84 & 30,12 \\
Estonia & 29,6 & 29,3 & 28,6 & 28,6 & 27,6 & 27,1 & 26,2 & 25,8 & 24,6 & 25,9 & 25,4 \\
Lithuania & 29,6 & 29,7 & 28,6 & 28,2 & 28 & 27,1 & 25,8 & 24,8 & 23,8 & 24,9 & 25,2 \\
Romania & 29,4 & 29,8 & 29,6 & 29,1 & 28,4 & 28,1 & 28 & 27,6 & 26,3 & 26,66 & 26,9 \\
Latvia & 27,1 & 27,1 & 26,5 & 26,1 & 25,5 & 24,7 & 23,6 & 22,8 & 21,3 & 22,9 & 23,2 \\
Cyprus & 26,5 & 26,2 & 26 & 25,6 & 25,2 & 25,7 & 24,8 & 24,4 & 23,6 & 23,8 & 24,2 \\
Poland & 25,9 & 25,4 & 25 & 24,4 & 23,8 & 23,5 & 23,3 & 23,1 & 22,2 & 22,8 & 23,2 \\
Slovenia & 24,6 & 24,3 & 24,1 & 23,6 & 23,1 & 23,5 & 23,3 & 22,6 & 22,4 & 22,9 & 23,4 \\
Italy & 22 & 21,8 & 21,2 & 21,6 & 21,1 & 20,8 & 20,6 & 20,2 & 19,8 & 22,4 & 22,8 \\
Portugal & 19,5 & 19,2 & 19,4 & 19,4 & 19 & 18,7 & 17,6 & 17,2 & 16,6 & 16,8 & 17,6 \\
Spain & 19,5 & 19,4 & 19,2 & 19,2 & 18,6 & 18,5 & 18,2 & 17,8 & 17,2 & 17,6 & 18,2 \\
Belgium & 17,8 & 17,4 & 17,1 & 16,8 & 16,4 & 16,1 & 16,6 & 16,2 & 15,6 & 16,4 & 16,9 \\
Czechia & 16,9 & 16,7 & 16,4 & 16 & 15,5 & 15,3 & 15,1 & 14,8 & 14,1 & 14,6 & 15,2 \\
Slovakia & 16,8 & 16,4 & 16 & 15,5 & 15 & 14,6 & 14,1 & 15,9 & 22,4 & 17,2 & 17,9 \\
Sweden & 15,4 & 15 & 14,7 & 14,3 & 13,9 & 13,6 & 13,3 & 13,9 & 12,1 & 12,8 & 13,8 \\
Germany & 14,6 & 13,9 & 13,7 & 13,3 & 13 & 13,3 & 12,2 & 11,6 & 10,4 & 10,9 & 11,8 \\
Denmark & 14,3 & 14,3 & 14 & 13,7 & 13,3 & 12,8 & 12 & 11,2 & 10,9 & 11,4 & 11,6 \\
Finland & 14,2 & 14 & 13,7 & 13,3 & 13 & 12,9 & 12,4 & 12,2 & 11,5 & 11,8 & 12,3 \\
Ireland & 13,1 & 13 & 12,8 & 12,7 & 12,2 & 11,8 & 11,3 & 11,7 & 11,5 & 11,9 & 11,6 \\
France & 11,6 & 11,3 & 11 & 10,8 & 9,9 & 10,8 & 12,3 & 12 & 12,8 & 12,6 & 12,1 \\
Netherland & 10,2 & 10 & 9,8 & 9,5 & 9,1 & 9,2 & 9 & 8,6 & 8,4 & 8,9 & 9,1 \\
\hline Luxembourg & 8,8 & 8,4 & 8,2 & 8,2 & 8 & 8,1 & 8,3 & 8,1 & 8,2 & 8 & 8,4 \\
Austria & 8,47 & 8,2 & 7,9 & 7,6 & 7,5 & 7,8 & 8,2 & 7,9 & 7,1 & 7,4 & 7,6 \\
\hline
\end{tabular}

world Romania finalPDF.pdf, Eurostat, https://www.theglobaleconomy.com/rankings/shadow economy/Europe/ 
According to Table 1, it is observed that Romania registered a value of $26.9 \%$ of GDP (it is a high value compared to the other countries analyzed) in 2019 in terms of the shadow economy, but Bulgaria has a larger underground economy (30.12\% of GDP).

Table 2. The development of the shadow economy (in \% of GDP) of Romania, 2009-2019

\begin{tabular}{|c|c|c|}
\hline Years & $\begin{array}{c}\text { The shadow economy } \\
\text { (in \% of GDP) }\end{array}$ & $\begin{array}{c}\text { GDP } \\
\text { (millions of euros) }\end{array}$ \\
\hline $\mathbf{2 0 0 9}$ & 29,4 & 118,3 \\
\hline $\mathbf{2 0 1 0}$ & 29,8 & 125,4 \\
\hline $\mathbf{2 0 1 1}$ & 29,6 & 131,8 \\
\hline $\mathbf{2 0 1 2}$ & 29,1 & 132,7 \\
\hline $\mathbf{2 0 1 3}$ & 28,4 & 144,7 \\
\hline $\mathbf{2 0 1 4}$ & 28,1 & 150,8 \\
\hline $\mathbf{2 0 1 5}$ & 28 & 160,1 \\
\hline $\mathbf{2 0 1 6}$ & 27,6 & 170,4 \\
\hline $\mathbf{2 0 1 7}$ & 26,3 & 187,8 \\
\hline $\mathbf{2 0 1 8}$ & 26,66 & 204,4 \\
\hline $\mathbf{2 0 1 9}$ & 26,9 & 223,3 \\
\hline
\end{tabular}

Source: Elaborated by the authors, data from https://cdn.cursdeguvernare.ro/wp-content/uploads/2020/02/Shadow-EcScannedaround-the-world Romania finalPDF.pdf and Eurostat https://appsso.eurostat.ec.europa.eu/nui/show.do?dataset=nama 10 gdp\&lang=en

According to the latest edition of the Schneider Study, for 2019, Romania's unobserved economy amounts to $26.9 \%$ of GDP.

Table 2 shows that the shadow economy in the analyzed period 2009-2019 registered a decreasing trend in 2017 respectively, 26.3\%, and in 2019 registering a value of $26.9 \%$ of GDP. The highest value recorded was in $2010-29.8 \%$ of GDP, respectively an increase of $1.36 \%$ compared to 2009 . The lowest values of the shadow economy in 2019 were recorded by Austria, Luxembourg and the Netherlands.

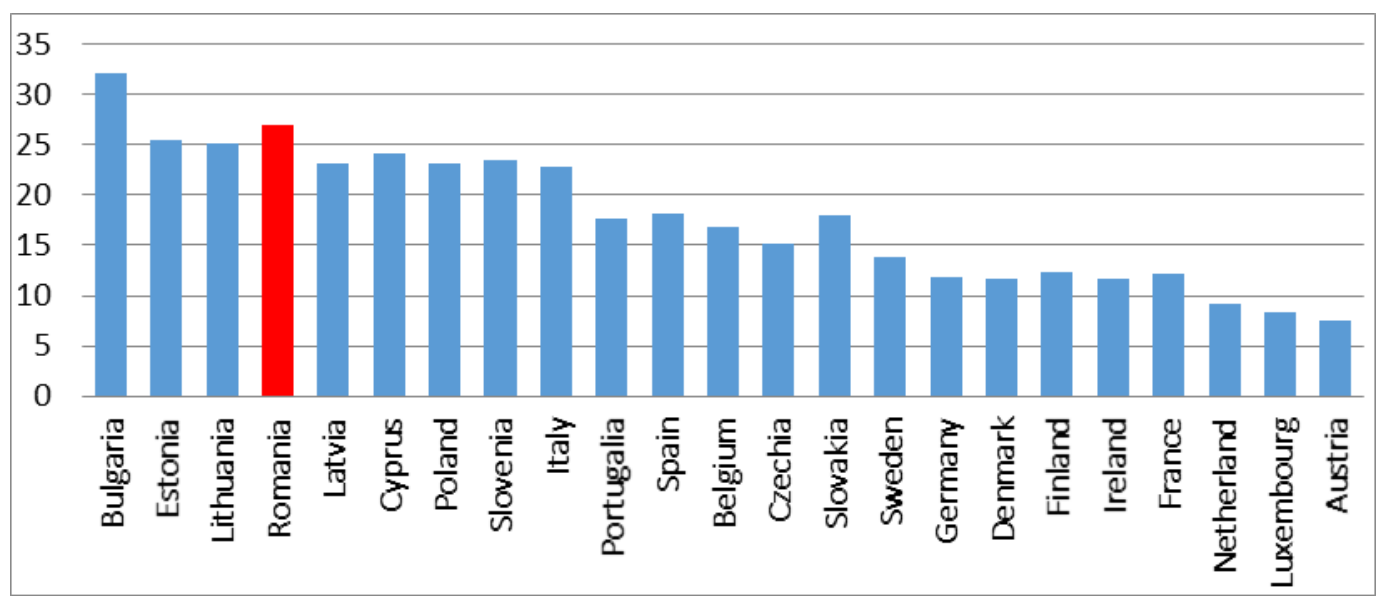

Figure 1. Size of the Shadow Economy of European Countries, 2019 (in \% of off. GDP) Source: Developed by the authors, information available on Table 1

In Figure 1, in 2019, Romania registered a high value in terms of the shadow economy, respectively (26.9\% of GDP), being surpassed by Bulgaria. The shadow economy is smaller in economically advanced OECD countries than in Central and Eastern European countries.

The level of compliance with tax rules remains declining, as evidenced by the high rate of noncollection of value added tax. The deficit in value added tax (VAT) is defined as the difference between the obligation to pay the VAT due and the VAT collected. Therefore, this deficit represents a loss of revenue due to tax evasion, fraud, insolvencies, bankruptcies or legal tax optimization. 


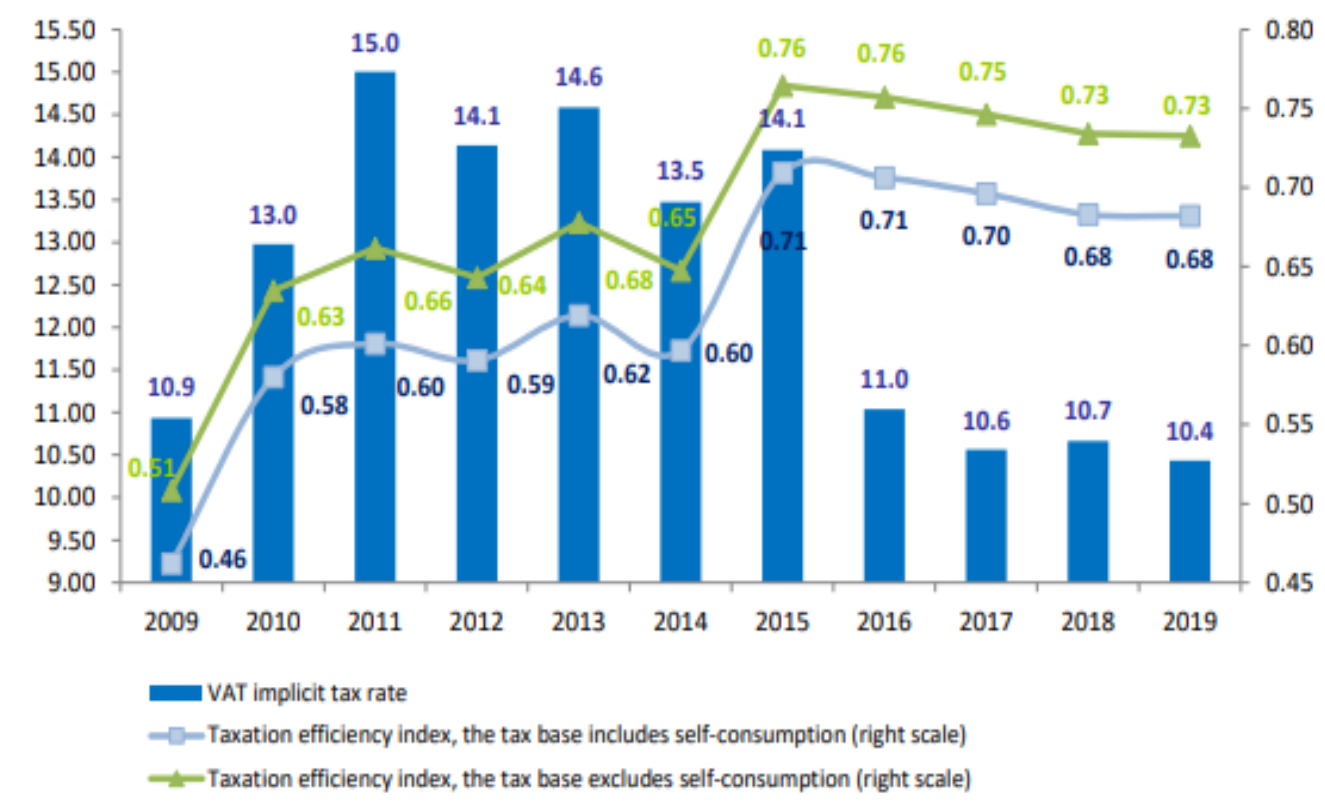

Figure 2. The evolution of the implicit tax rate and the taxion efficiency index for VaT in Romania

Source: 2019 Annual Report, RA CF 2019.pdf(consiliulfiscal.ro)

Figure 2 shows the evolution of the implicit tax rate and the efficiency index of VAT collection in Romania. It can be seen, analyzing the evolution of the VAT collection efficiency index, that after a period of relative stability 2010-2014, 2015 marked a significant improvement in the efficiency of VAT collection. Subsequently, in the period 2016-2019, the efficiency index suffered minor decreases.

Table 3. Taxation efficiency VAT, corporate income tax, personal income tax, social security contributions in Romania, 2017-2019

\begin{tabular}{lccc}
\hline \multicolumn{1}{c}{ Indicator } & $\mathbf{2 0 1 7}$ & $\mathbf{2 0 1 8}$ & $\mathbf{2 0 1 9}$ \\
\hline Taxation efficiency - VAT & 14,1 & 14,5 & 14,2 \\
\hline Weighted average VAT rate (\%) & 9,9 & 9,9 & 9,7 \\
\hline Implicit tax rate (\%) & 0,70 & 0,68 & 0,68 \\
\hline Taxation efficiency index & & & \\
Taxation efficiency - corporate income tax & 16 & 16 & 16 \\
\hline Legal corporate income tax rate (\%) & 4,0 & 4,3 & 4,3 \\
\hline Implicit tax rate (\%) & 0,25 & 0,27 & 0,26 \\
Taxation efficiency index & & & \\
Taxation efficiency - personal income tax & 16 & 10 & 10 \\
Legal personal income tax rate (\%) & 12,8 & 7,1 & 7,9 \\
Implicit tax rate (\%) & 0,80 & 0,71 & 0,79 \\
Taxation efficiency index & & & \\
Taxation efficiency - social security contributions & 39,4 & 38,2 & 36,2 \\
\hline Legal social security contributions (\%) & 27,3 & 28,9 & 28,9 \\
\hline Implicit tax rate (\%) & 0,69 & 0,78 & 0,78 \\
\hline Taxation efficiency index & & \\
\hline
\end{tabular}

Source: Elaborated by the authors, data from RA CF 2019.pdf (consiliulfiscal.ro)

The collection efficiency index increased significantly for direct taxes paid by the population, stagnated in the case of VAT and social security contributions, and recorded a slight decrease for direct taxes paid by companies. The collection efficiency index in the case of direct taxes paid by the population increased (from 0.71 in 2018 to 0.79 in 2019), but this is not due to income tax revenues, but other taxes included in this category. In comparison, the efficiency of collecting direct taxes paid by companies registered a slight decrease (from 0.27 in 2018 to 0.26 in 2019), the analysis of the revenue structure related to this budgetary indicator showing a slower evolution of the profit tax paid by economic operators in the non-financial sector, partially offset by the profit tax advance paid by commercial banks. The large shadow economy creates additional challenges in terms of compliance with tax rules. 
According to the National Bank of Romania, tax evasion is favored by the frequent use of cash payments, with cash payments exceeding electronic payments four times. Only $77 \%$ of all bank cards are active, in the context of a relatively low level of financial education. In 2018, in Romania, only 58\% of adults have a bank account, compared to $94 \%$ in high-income economies and $63 \%$ in developing countries.

Undeclared work is a form of tax evasion that undermines the sustainability of public finances and fiscal stability. Undeclared work can be classified into three basic categories (according to European Commission):

\# undeclared work in an official company. This type of work can be completely or partially undeclared, part of the salary being paid officially, and another part illegally;

* undeclared self-employment or undeclared self-employment, which provides services to either an official company or other clients, such as households;

* providing goods and services to neighbors, family or acquaintances. Sometimes this form of work is like mutual assistance.

All this facilitates the spread of the shadow economy and tax evasion.

\section{Conclusions}

Tax evasion occurs when a person or company illegally avoids paying its tax liability, which is an accusation that is subject to sanctions and fines. Tax evasion, on the other hand, uses illegal means to avoid paying taxes. Usually, tax evasion involves hiding or distorting income.

The reduction of the shadow economy and tax evasion is primarily due to a set of coherent economic and financial policy measures, which ensure the security of a medium-term business plan for employers. Then, every investor needs to have the assurance that his business does not need political protection.

The Romanian state should take all necessary measures for at least part of the shadow economy to be brought into the official economy, by reducing tax evasion through measures such as:

* simplification of tax administration procedures to support voluntary compliance with the declaration of tax obligations;

\& simplification of compliance with the payment of tax obligations;

* ensuring a differentiated tax treatment according to the tax behavior of taxpayers;

$\$$ extension and improvement of electronic control techniques;

\# national identification of affiliated persons;

* initiation of tax inspections in accordance with the BEPS (Base Erosion and Profit Shifting)

Tax evasion is a huge problem and affects every European citizen. Tax evasion must be treated as a matter of priority, and administrative and legislative reforms must be supported by careful monitoring and reduction.

\section{References}

1. Alm, J., Martinez-Vazquez, J., Tax Morale and Tax Evasion in Latin America, Andrew Young School of Policy Studies, Georgia University, International Studies Program,W.P., 2007

2. Brașoveanu I.V, Economia subterană și corupția: probleme majore ale economiei românești, Review Economie teoretică și aplicată, vol.XVII, 2010, available at http://store.ectap.ro/articole/529 ro.pdf

3. Brown C.V., Jackson P.M., Public Sector Economics, Second Edition, Basil Black-well, Oxford, 1982.

4. Choi, J. P. and Thum, M., Corruption and The Shadow Economy, International Economic Review, Vol. 46, No. 3., 2005

5. Manea L.D., Muntean M.C., Nistor R., The impact of the Shadow Economy in Romania, Risk in Contemporary Economy 2020, pp.222-229

6. Medina L., Schneider F., Shadow Economies Around the World: What Did We Learn Over the Last 20 Years?, available at http://pinguet.free.fr/fmi1817.pdf

7. Rădulescu (Toader), S., Evaziunea fiscală în România în perioada de tranziție, ASE, București, 2007

8. Schneider, F., Shadow Economies and Corruption All Over the World: New Estimates for 145 Countries, Economics Journal, 2007

9. Schneider, F. , Size and Development of the Shadow Economy of 31 European and 5 other OECD Countries from 2003 to 2015: Different Developments, 2015

10. Tudose B.M, Clipa R.I, An analysis of the shadow economy in EU countries, CES Working Papers - Volume VIII, Issue 2, available at https://ceswp.uaic.ro/articles/CESWP2016 VIII2 TUD.pdf

11. Văcărel, I. și colectivul, Finanțe publice, Editura Didactică și Pedagogică, Bucureşti, 2007

12. Voicu C., Criminalitatea afacerilor, Tipografia IPG, Bucuresti, 1997

13. BNR, https://www.bnr.ro

14. European Commission, $\underline{\text { https://ec.europa.eu }}$

15. Eurostat, https://appsso.eurostat.ec.europa.eu/nui/show.do?dataset=nama 10 gdp\&lang=en

16. Raport anual, Consiliul Fiscal 2019, available at RA CF 2019.pdf(consiliulfiscal.ro)

17. Raport de tară 2019 privind România, available at https://ec.europa.eu/info/sites/info/files/file import/2019-european-semestercountry-report-romania_ro.pdf

18. https://cdn.cursdeguvernare.ro/wp-content/uploads/2020/02/Shadow-EcScanned-around-the-world Romania finalPDF.pdf

19. https://www.oecd.org/unitedstates/publicationsdocuments/reports/

20. https://usv.ro/fisiere utilizator/file/Doctorat/2017/05/baicu/04 Rezumat Teza lb ro Baicu.pdf

21. http://www.consiliulfiscal.ro/ionut site.pdf; https://www.fiscalitatea.ro

22. https://www.theglobaleconomy.com/rankings/shadow_economy/Europe/, 